\title{
The anterograde and retrograde infusion of glucagon antibodies suggests that $A$ cells are vascularly perfused before $D$ cells within the rat islet
}

\author{
J. I.Stagner ${ }^{1}$, E. Samols ${ }^{1}$ and V.Marks ${ }^{2}$ \\ ${ }^{1}$ V.A. Medical Center and the Department of Medicine, School of Medicine, University of Louisville, Louisville, Ky, USA, and \\ ${ }^{2}$ Department of Biochemistry, University of Surrey, Surrey, UK
}

\begin{abstract}
Summary. We have suggested that the order of cellular vascular perfusion within the islet is important in the regulation of islet hormone secretion. Anatomically, the A and D cells appear to be randomly dispersed throughout the mantle. Although islet capillary blood flow is known to be from the Bcell core to the A- and D-cell mantle, it has not yet been established whether the cells of the mantle may influence one another vascularly. Rat pancreata were perfused in vitro anterogradely and retrogradely with or without glucagon antibody in order to determine the order of cellular perfusion and interaction between the A and D cells in the islet mantle. Anterograde infusion of glucagon antibody did not affect insulin secretion, but rapidly decreased somatostatin secretion $-46 \pm 8 \%,(p<0.005)$. Retrograde infusion of glucagon anti-
\end{abstract}

body decreased insulin secretion $(-27 \pm 8 \%, p<0.005)$ but had no effect upon somatostatin secretion. This study not only confirms a core to mantle islet perfusion but also establishes that the A cell precedes the $\mathrm{D}$ cell in the terms of vascular perfusion. Thus within the islet, vascular borne insulin regulates the release of glucagon, which in turn, regulates the release of somatostatin. Somatostatin is vascularly neutral owing to its downstream position in the sequence (B to $A$ to $D)$ of cellular perfusion.

Key words: Islet secretion, A and D cells, vasculature, perfusion, mantle, interactions, paracrine, insulin, glucagon, somatostatin.
The endocrine cells of the pancreatic islet are responsible for the production and the secretion of hormones to regulate hepatic carbohydrate metabolism. Histological studies have shown that the rat and human islet is composed of a core of insulin producing $B$ cells and a mantle of A and D cells which secrete glucagon and somatostatin respectively [1]. The division of islet cell types into distinct regions led to the suggestion that adjacent cells within the islet might influence one another [1-3], depending upon the prevailing glucose concentration and autonomic neural stimulation [4]. That insulin and glucagon affected the secretion of each other in a negative-positive interaction [4, 5 and refs. therein] bolstered the concept that net hormone secretion from the islet may be the result of specific intra-islet cellular interactions $[4,6]$. However, physiological studies, infusing glucose or exogenous hormones had not been able to establish whether there is a strict sequence of cellular perfusion and interaction within the islet. From these studies, it could have been argued either that $\mathrm{A}$ and $\mathrm{D}$ cells regulate the $\mathrm{B}$ cell (mantle-to-core) or that the $B$ cell regulates the $A$ and $D$ cell (core-to-mantle) de- pending upon the direction of cellular perfusion within the islet.

For many years, it was assumed that insulin secretion was modulated by glucose, as well as by the influx of glucagon and somatostatin from A and D cells, anatomically considered to be perfused before the B cells [7, 8]. Recently, the mantle-to-core hypothesis has been challenged by the histological reconstruction of serially sectioned rat islets and electron microscopy of methacrylate casts of the islet microvasculature [9]. In rat islets, the afferent vessel, an arteriole, enters the islet at a gap in the non-continuous mantle of A, D and PP cells. Immediately after entering the islet, the arteriole branches into multiple capillaries, which first traverse the B cell core before they pass through the non- $B$ cell mantle where upon they form collecting venules. The histology of the islet implies that the A and D cells are randomly dispersed throughout the mantle. From the apparent random order of $A$ and $D$ cells and the often conflicting results from the infusion of exogenous islet hormones, it is unclear whether the cells of the mantle vascularly influence one another or whether an interaction, if pres- 


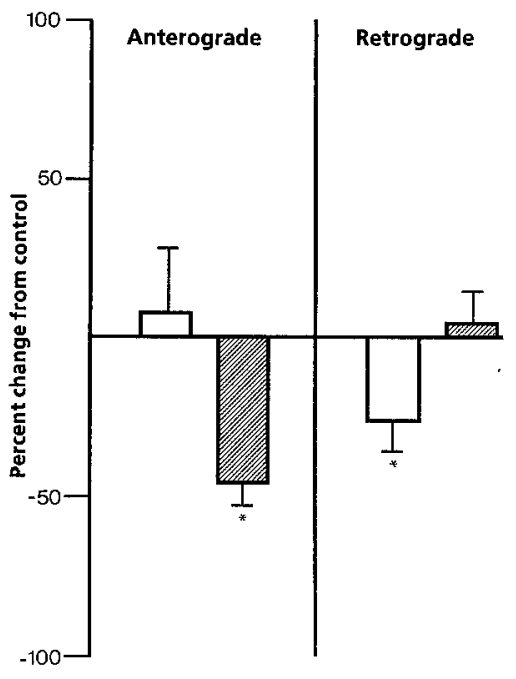

Fig. 1. The effect of anterograde or retrograde infusion of glucagon antibody upon insulin and somatostatin secretion. Core-tomantle vascular perfusion is assumed during anterograde perfusion. $\square$ insulin, somatostatin, ${ }^{*} p<0.005$

ent, would be from the A cell to the D cell or from the $\mathrm{D}$ cell to the A cell. Studies perfusing the dog pancreas in vitro [10,11], as well as studies infusing insulin or somatostatin antibody into the isolated rat pancreas [12, 13], have suggested that the sequence of cellular perfusion and interaction in the islet may be $B$ to $A$ to $D$. If this proposed order is correct, the D cell may be the last perfused and may be regulated by the A cell through vascular channels.

\section{Materials and methods}

In order to confirm that the A and D cells in the mantle are ordered in terms of vascular cellular perfusion and to confirm our previously proposed $B$ to $A$ to $D$ order of cellular perfusion, [10-12] rat pancreata (Sprague-Dawley, Indianapolis, Ind, USA) were isolated and perfused both anterogradely (normal arterial perfusion) or retrogradely (reversed, i.e. venous perfusion) with anti-glucagon antibody (Guildhay, Surrey, UK). The method for pancreatic isolation and perfusion are described in detail elsewhere $[10,12,14]$. Pancreata were perfused at $2 \mathrm{ml} \cdot \mathrm{min}^{-1}$ for $60 \mathrm{~min}$ with Krebs-Ringer buffer $\mathrm{pH} 7.4$ containing $5 \mathrm{mmol} / 1$ glucose. Retrograde perfusion was achieved by rapidly switching the efflux and influx tubing, resulting in perfusion via the portal vein and efflux collection via the aorta. The first $35 \mathrm{~min}$ of perfusion in either direction were used as a control period preceding a $10 \mathrm{~min}$ infusion of glucagon antibody. The methods for the isolation of gamma globulin and the quantitation of glucagon binding by the antibody $[12,13]$, have been previously described. All animals were anesthetised prior to surgery with sodium pentobarbital. Insulin and somatostatin efflux concentrations were measured by radioimmunoassay using a charcoal separation method [15].

\section{Statistical analysis}

Statistical analysis was performed by Student's t test for paired observations and analysis of variance (ANOVA). Results are reported as the mean \pm standard error of the mean.

\section{Results}

As shown in Table 1 and Figure 1, the anterograde infusion of glucagon antibody had no effect upon insulin secretion, but strongly reduced somatostatin secretion. Pre-infusion efflux concentrations of somatostatin were obtained 3-5 min after the cessation of antibody infusion. Conversely, the retrograde infusion of glucagon antibody had no effect upon somatostatin secretion but slightly decreased insulin secretion. As noted above, pre-antibody infusion levels of insulin were obtained 3-5 min after the cessation of antibody infusion.

Glucagon binding by the antibody, under conditions simulating a perfusion $[12,13]$, was in excess of $2000 \mathrm{ng} / 1$ at a flow rate of $0.1 \mathrm{ml}$ antibody $\cdot \mathrm{min}^{-1}$. Efflux glucagon concentrations prior to the infusion of glucagon antibody were $120 \pm 9 \mathrm{pg} \cdot \mathrm{min}^{-1}$ anterogradely and $151 \pm 25 \mathrm{pg} \cdot \mathrm{min}^{-1}$ retrogradely. Perfusate glucagon concentrations during glucagon antibody perfusions were less than $1 \mathrm{pg} \cdot \mathrm{min}^{-1}$ regardless of the direction of perfusion. As previously reported [12], there was no difference in efflux volume between anterograde and retrograde perfusions. Perfusion pressure increased only 1-3 $\mathrm{mm} \mathrm{Hg}$ after the reversal of flow from an arterial perfusion pressure of $30-35 \mathrm{~mm} \mathrm{Hg}$. No significant edema was noted.

\section{Discussion}

The infusion of anti-glucagon antibody was expected to neutralize vascular intra-islet glucagon, regardless of the direction of perfusion. Three permutations of cellular interactions are possible based upon the sequence of cellular perfusion consistent with a core-to-mantle vascular flow (Fig.2). If the sequence of cellular perfusion during anterograde perfusion were B-A-D, anti-glucagon antibody should have no effect upon insulin secretion because the A cell would be distal to the B cell.

Table 1. Change in insulin and somatostatin secretion in the presence of glucagon antibody

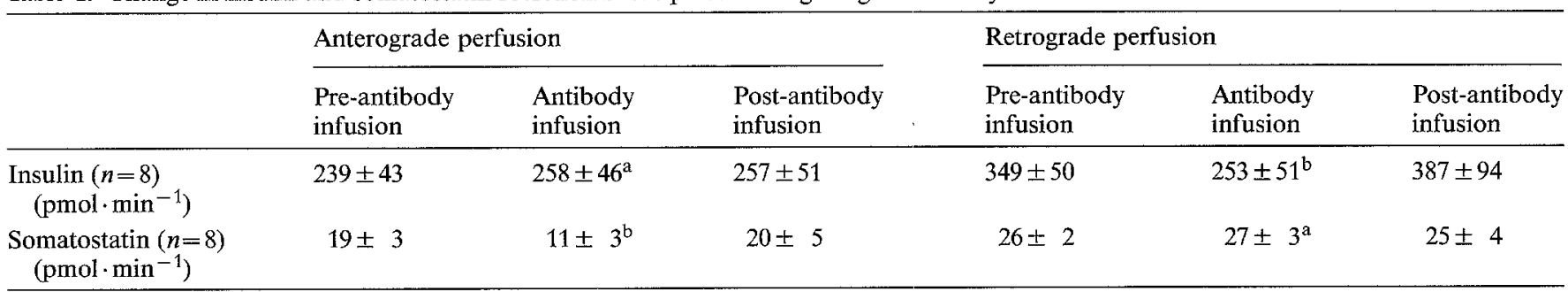

\footnotetext{
a Not statistically significant versus pre-antibody infusion concentrations, by ANOVA and Student's t test for paired comparisons;
}

${ }^{\mathrm{b}} p<0.005$ versus pre-antibody concentrations; $n=$ number studied 
However, the addition of glucagon antibody should decrease the secretion of somatostatin from pre-antibody infusion values by a reduction of glucagon-stimulated somatostatin secretion. The retrograde infusion of glucagon antibody should have no effect upon somatostatin secretion as the A cell would now be vascularly distal to the $\mathrm{D}$ cell. In addition during retrograde glucagon antibody infusion, insulin secretion should decrease owing to a reduction in glucagon-stimulated insulin secretion. If the cellular sequence were B-D-A, anterograde glucagon antibody infusion should have no effect upon the B or D cell because in this sequence the A cell would be furthest downstream. Conversely, during retrograde perfusion, the addition of glucagon antibody should result in a diminution of both insulin and somatostatin from control concentrations (Fig. 2). The third permutation which permits a core-to-mantle perfusion would be a totally random order of $\mathrm{A}$ and $\mathrm{D}$ cells in the mantle. Here the anterograde infusion of glucagon antibody should have no effect upon the B cell and may have no effect or a slight suppressive effect upon the D-cell. Retrograde infusion of glucagon antibody would be expected to reduce insulin secretion, but the secretion of somatostatin should be identical to that obtained during anterograde perfusion.

Because it has been demonstrated that antibody proteins do not readily cross the capillary endothelium within the exocrine [16] or endocrine pancreas [12, 13], the diametrically opposed effects of anterograde and retrograde glucagon antibody perfusion upon insulin and somatostatin is strong evidence against a non-specific or idiotypic antibody effect and also argues against the rapid passage of antibody into the interstitial space, where it may influence possible paracrine interactions. The present results are consistent with a core-to-mantle direction of vascular flow and cellular interaction as previously proposed [9-12]. At present, there are no histological methods available to demonstrate how an ordered sequence of cellular perfusion may exist within the mantle, despite the histologically-appearing random distribution of the A and $\mathrm{D}$ cells.

The present results, as well as those previously reported from the infusion of either insulin or somatostatin antibody $[12,13]$, establish that, on a physiological basis, there is an ordered sequence of cellular perfusion within the mantle and confirm, that the majority of the A cells are perfused before the majority of $D$ cells. The presence of a specific order of cellular perfusion $(\mathrm{B} \rightarrow \mathrm{A} \rightarrow \mathrm{D})$ within the islet has several important physiological consequences. In terms of the microvascular sequence of perfusion, the B cell is the primary glucose sensor and has a dominant role in the inhibition of glucagon secretion [9-13]. An increase in glucose in the physiological range has been shown not to have a significant effect upon the A cell in the absence of insulin in the intact islet [ 2 and refs. therein, 10, 15, 17]. The abnormalities of glucagon secretion reported in Type 1 (insulin-dependent) and 2 (non-insulin-depend-
CELLULAR ORDER ANTEROGRADE PERFUSION RETROGRADE PERFUSION

\section{ANTI-GLUCAGON ANTIBODY}

$\begin{array}{ll}B \rightarrow A \rightarrow D & I-S S \downarrow \\ B \rightarrow D \rightarrow A & I-S S- \\ B \rightarrow A \text { AND D RANDOM } & I-S S-O R \downarrow\end{array}$

$I$ SS -
$I$ SS $\downarrow$
$I$ SS (SAME AS ANTEROGRADE)

Fig. 2. Changes in hormone secretion predicted by the possible sequence of vascular cellular perfusion within the islet. The above permutations of cellular perfusion sequence are consistent with a coreto-mantle direction of capillary blood flow. SS (somatostatin), I (Insulin), $\uparrow$ (Increase), $\downarrow$ (Decrease), ↔ (No Change) $\downarrow$ (Slight Decrease)

ent) diabetes, based on the infusion of arginine, glucose or insulin [2, 18 and refs. therein], may be explainable respectively in terms of absolute or relative deficiency in intra-islet microvascular insulin.

In a core-to-mantle $\mathrm{B} \rightarrow \mathrm{A} \rightarrow \mathrm{D}$ sequence of perfusion, the $D$ cell should have no effect upon A or B cells through vascular channels. Because the D cells are furthest downstream, the A and B cells are not exposed to high concentrations of vascular intra-islet somatostatin, thus maintaining their sensitivity to low concentrations of somatostatin entering the pancreas from the systemic circulation $[19,20]$. Owing to the extreme sensitivity of the $\mathrm{A}$ and $\mathrm{B}$ cells to low concentrations of exogenous somatostatin $[19,20]$ and the agonist-antagonist effects of a somatostatin-inhibiting analogue [21], it has been suggested that the $\mathrm{D}$ cell may be a primary candidate for the paracrine regulation of islet hormone secretion. The placement of the D cell as last in line, in terms of vascular communication within the islet, does not prohibit the possibility of paracrine regulation of islet hormone secretion via diffusion of hormones through the islet interstitial fluid spaces. It has been assumed that interstitial fluid flow paralleled the direction of capillary blood flow. However, a recent report [22] has suggested a "counter current" mechanism for interstitial somatostatin by either fluid flow opposite the capillary flow or the presence of pseudopod-like processes from the D cell [23] which could facilitate or localise paracrine (interstitial) regulation to specific cellular domains within the islet [24] in reach of the D cell. It is, therefore, possible that paracrine somatostatin may partially restrain the A cell in Type 1 diabetes, preventing an even more severe hyperglucagonaemia. It must be noted that true paracrine events have not been unequivocally demonstrated in either normal or diabetic islets $[4,25]$ and can not be proven or disproven without knowledge of the functional contribution of the intraislet microvascular circulation to islet regulation.

In summary the presence of an ordered sequence of islet cell perfusion within the islet mantle has been established by the present study, substantiating and extending the core-to-mantle circulatory model of Bonner-Weir and Orci [9]. Because physiological changes in glucose do not affect the A cell in the intact islet $[10,11$, $13,17]$, the $\mathrm{B}$ cell is vital to the regulation of glucagon secretion. Thus, the B cell regulates the A cell [10-13, 
17] which in turn regulates the $D$ cell through the islet microvasculature. The $\mathrm{D}$ cell is vascularly neutral. The sequence of cellular perfusion has a major role in islet regulation and metabolic homeostasis. This role is not only tonic as demonstrated by the present studies but is also dynamic, regulating moment to moment changes in islet hormone responses to fuels and metabolites, as may be inferred from the rapid change of insulin and glucagon when the glucose level perfusing the pancreas is increased within the physiological range. The use of the anterograde versus retrograde perfusion technique coupled with specific intravascular ligand neutralisation should provide important information in the study of cellular relationships in organ physiology.

Acknowledgements. The author wishes to thank J.Faircloth and K. Hodge for their skillful technical assistance and S. James for the preparation of the manuscript. Supported by grants from the Veterans Administration, the University of Louisville, the Norton Research Fund and the Diabetes Research and Education Foundation.

\section{References}

1. Orci L, Unger RH (1975) Functional subdivision of islets of Langerhans and possible role of D cells. Lancet II: 1243

2. Orci L, Malaisse-Lagae F, Rouiller D, Renold AE, Perelet A, Unger RH (1975) A morphological basis for intercellular communication between alpha and beta cells in the endocrine pancreas. J Clin Invest 56: 1066-1070

3. Haist RE (1965) Effects of changes in stimulation on the structure and function of islet cells. In: Leibel BS, Wrenshall GA (eds) On the nature and treatment of diabetes. Excerpta Medica, Amsterdam, pp 12-130

4. Samols E, Weir GC, Bonner-Weir S (1983) Intraislet insulin-glucagon somatostatin relationships. In: Lefebvre PJ (ed) Handbook of experimental pharmacology, Vol 66/II. Springer, Berlin Heidelberg New York, pp 133-173

5. Samols E, Tyler J, Marks V (1972) Glucagon-insulin interrelationships. In: Lefebvre PJ, Unger RH (eds) Glucagon. Molecular physiology, clinical and therapeutic implications. Pergamon Press, Oxford, pp 151-173

6. Unger RH, Orci L (1977) Hypothesis: the possible role of the pancreatic $D$ cell in the normal and diabetic states. Diabetes 26 : $241-244$

7. Fujita T, Yanatori Y, Murakomi T (1976) Insulo-acinar axis, its vascular basis and its functional and morphological changes caused by CCK-PZ and caerulein. In: Fujita $T$ (ed) Endocrine gut and pancreas. Elsevier, Amsterdam, pp 347-358

8. Fujita T (1985) Morphology of islet blood supple. In: Lainer J, Pohl SL (eds) Methods in diabetes research, Vol. I, Part C. WileyInterscience, New York, pp 325-332

9. Bonner-Weir S, Orci L (1982) New perspectives on the microvasculature of the islets of Langerhans in the rat. Diabetes 31: 883-889
10. Stagner JI, Samols E (1986) Retrograde perfusion as a model for testing the relative effects of glucose versus insulin on the A cell. J Clin Invest 77: 1034-1037

11. Stagner JI, Samols E, Bonner-Weir S (1988) $\beta \rightarrow \alpha \rightarrow \delta$ Pancreatic islet cellular perfusion in dogs. Diabetes $37: 1715-1721$

12. Samols E, Stagner JI, Ewart RBL, Marks V (1988) The order of islet microvascular cellular perfusion is $\mathrm{B} \rightarrow \mathrm{A} \rightarrow \mathrm{D}$ in the perfused rat pancreas. J Clin Invest $82: 350-353$

13. Maruyama H, Hisatomi A, Orci L, Grodsky GM, Unger RH (1984) Insulin within islets is a physiologic glucagon release inhibitor. J Clin Invest 74: 2296-2299

14. Grodsky GM, Heldt H (1984) Method for the in vitro perfusion of the pancreas. In: Larner J, Pohl SL (eds) Methods in diabetes research, Vol I, part B. Wiley, New York, pp 137-146

15. Weir GC, Samols E, Loo S, Patel YC, Gabbay KH (1979) Somatostatin and pancreatic polypeptide secretion: effects of glucagon, insulin and arginine. Diabetes $28: 35-40$

16. Kvietys PR, Perrey A, Grange DN (1983) Permeability of pancreatic capillaries to small molecules. Am J Physiol 245: G519-G524

17. Maruyama $H$, Tominaga M, Bolli G, Orci L, Unger RH (1985) The alpha cell response to glucose change during perfusion of anti-insulin serum in pancreas isolated from normal rats. Diabetologia $28: 836-840$

18. Unger RH (1981) The milieu interieur and the islet of Langerhans. Diabetologia 20: 1-11

19. Kawai K, Ipp E, Orci L, Perellet A, Unger RH (1982) Circulating somatostatin acts on the islets of Langerhans by way of a somatostatin-poor compartment. Science 218: 477-478

20. Samols E, Harrison J (1976) Remarkable potency of somatostatin as a glucagon suppressant. Metabolism 25: 1495-1497

21. Taborsky GJ Jr (1983) Evidence of a paracrine role for pancreatic somatostatin in vivo. Am J Physiol 245: E 598-E 603

22. Stagner JI, Samols E, Taborsky GJ (1987) Mediation of B-cell secretion by intra-islet somatostatin. Diabetes 36:7 (Abstract)

23. Larsson LS, Goltermann N, de Magistris L, Rehfeld IF, Schwartz TW (1979) Somatostatin cell processes as pathways for paracrine secretion. Science 205: 1393-1395

24. Meda P, Perrelet A, Orci L (1982) Endocrine cell interactions within the islets of Langerhans. In: Pritts JD (ed) Functional integration of cells in animal tissues. Cambridge University Press, Cambridge, pp 113-131

25. Samols E, Bonner-Weir S, Weir GC (1986) Intra-islet-insulinglucagon-somatostatin relationships. Clin Endocrinol Metab 15: $33-58$

Received: 13 September 1988

and in revised form: 16 January 1989

Dr. J.I. Stagner

Research Service (151)

V.A. Medical Center

800 Zorn Avenue

Louisville, Ky 40202

USA 